Bernal holds that neither Britain's seientific effort nor her industry is adequate to face the change. Besides higher expenditure on sciontific rosoarch, he urges both expansion and reform in education and a determined effort to avoid waste of trained manpower.

\section{Overcrowding in Schools}

UNDER the title What Chance Has Your Child? (A Study of the Effocts of Overcrowded Classes in Our Schools. Pp. 15. London: National Union of Teachers, 1965. 6d.), the National Union of Teachers has issued a pamphlet by Miss K. Gibberd, to which Sir Ronald Gould contributes an introduction, describing the effects of overcrowded classes in terms of the children and tcachers involved. In England and Wales some $75 \cdot 1$ per cent of all children in primary schools are being taught in classes of thirty or more, and $17 \cdot 7$ per cent in classes of forty or more, while in secondary schools 51.7 per cent are being taught in classes of thirty or more. Sir Ronald Gould believes that if anything there is greater need for smaller classes in the primary schools than elsewhere. Miss Gibberd does not indulge in facile generalizations and what she writes about the frustration of both teachers and children is the more impressive. She also notes a tendeney, arising out of national parsimony, to calculate rigidly the needs of a school on the basis of one teacher and ono classroom to every forty children and no more of either until another forty children are added to the school roll. She emphasizes the key importance of a sufficient number of competent teachers, and her sensitive presentation of the human issues should promoto the public understanding, which is the only firm foundation for directing national resources to the appropriate end.

\section{Tracking Hurricanes}

Britarn is fortunatoly spared the terrible ravages of the giant tropical storms which may, and often do, sweep across the islands of the West Indies and the Gulf of Mexico, extending along the North American coast. The critical period of each year is from June to November, when these hurricanes, mostly born in mid-Atlantic, gather velocity and, following unpredictable, haphazard courses, roar across the Caribbean Islands and adjacent mainland, leaving doath and destruction in thoir trail. In years past there was apparently little in the way of organized scientific study of these hurricanes, particularly as a means of forewarning people in those places likely to lie in their path, in order that, given time, preparations could be made and safety measures taken accordingly. Often, tragically, there was no time, such is the speed and strength of theso furious storms. To-day, tracking of hurricanes has evolved into a highly organized branch of meteorology; search planes, rad ur, television-oquipped Tiros satellites, and an international communications system are used to follow and report every whirling storm of wind and rain as it devolops. Broadcast bullotins give advance warning to enable residents of threatened areas to take steps to protect lives, homes and property. Public education in the behaviour of hurricanes has proved to be the best means of reducing their toll. A brief account of this vital work is contained in a short article entitled "Tracking the Hurricanes" (The Lamp, Standard Oil Co. (New Jersey), New York, 47, No. 3, 1965). The Esso Stand ord Oil S.A., Ltd., the parent company's marketing affiliate in the West Indies, the Bahamas, Bermuda, Central America and Panama, in 1964 decided to help promotion of hurricane safety in the many widely scattered islands and regions where it operates, by the preparation of a hurricune tracking map for free distribu. tion by Esso dealers. The object of this publication was to make it possible for customers to follow brondewst storm reports, mark a hurricane's position by latitude and longitude, thus plotting its course from hour to hour. The article included information on the meaning of Weather Bureau returns, explanation of a storm's be. haviour, and suggested safety precautions. The circulation of this map exceeded 200,000; newspapers also reprinted it. The article includes a small-scale reproduction, as a grim reminder, of the paths of some destructive hurricanes of the past (1938-64); this was included with the original map in question. It is noted that similar hurricane maps were made available in 1965 and presumably the same facilities will operate in future years; this is a most praiseworthy and rewarding enterprise on the part of the oil company concerned.

\section{The Glaxo Volume}

The Glaxo Volume is the title of a most attractive publication which is described as "An occasional contribution to the Science and Art of Medicine", the twontyninth issue of which is now available (Glaxo Laboratories, Ltd., Greenford, Middlesex. Pp. 48. 29, 1965). At the outset it is pointed out that articles in The Glaxo Volume are contributed by medical and other scientists, including some of the technical staff of Glaxo Laboratories, Ltd. The authors remain anonymous for professional reasons. The first articlo is entitled "Fears for Food" and doals briefly with the necessity of discarding the concept of what is 'natural' about our foods and diets, and of considering, in the light of modern medical and nutritional science, what is wholesome and what is safe. The question of the use of food additives is diseussed; this posos tho problem of how much of the food additives or residues the eitizen is likely to consume in the ordinary course of events and what is going to be the effect of three, or six, or oven twenty times that amount. It is pointed out that even with the present limited number of 'permitted' additives or residues, monitoring their presence or effects in human or animal foods "is a protty forbidding task". The second article concerns "The Blood-Clotting Mechanism". This discusses what is known as the 'classical' theory (Morawitz, 1905), the 'augmented' classical theory (Owren, 1947), some information from haemophilia, opposing theories, the 'sequential' theory, evolution of the elotting mechanism, and the 'derivative' theory. This articlo includes some excellent explanatory diagrams in colour appropriate to the text. A third article is entitled "Pregnancy and Plumpness". The bolief that pregnancy predisposes to obesity is widespread but ". . . singularly little is known about the naturo of the weight gained during prognancy or about the natural history of body weight during the childbearing years". The problem is considered under the headings of woight gains during pregnancy, physiological storage of fat, variations in the pattorn and effect of age and parity on body-weight, and concludes with some practical considerations. In marked contrast is the article "Art in Bedlam", a short account of one Richard Dadd (1817-86), a painter whose imagination developed unusually during a long period in Bethlem Hospital (nicknamed 'Bedlam'); a reproduction of one of his paintings "The Fairy Follor's Master Stroke" (in colour), is shown. The fifth article is "Genetics and Drug Response", considered under the subheadings: blood groups, taste testing, haemoglobin 'Zurich' and sulphonamides, $X$ chromosome gene deficiencies and acetylation of isoniazid and other drugs. This article comes to the conclusion (inter alia) that "Unexpectedly wide variations can occur between responses of different people to the same dose of a drug. New drugs in particular should therefore be used with appropriate caution". Finally, an amusing, if not satirical, article entitled "Men are Not Machines" brings to a close this excellent publication which ono could wish was more than an occasional contribution to medical science.

\section{Solution to Waste-handling Problems}

There are many problems inherent to raw water clarification, conditioning of slimes and sludges, and other industrial and sanitary processes. Most cases, indeed, where suspended material has to be removed from aqueous 